DR. ALVARO FOIERI (Orcid ID : 0000-0001-5623-3629)

Article type : Regular Paper

\title{
Effect of host plant on the fitness of the spittlebug Notozulia entreriana: alternative method for rearing
}

\author{
Alvaro Foieri ${ }^{1 *}$, Eduardo Gabriel Virla ${ }^{2,3}$, Maciá Arnaldo ${ }^{4}$ \& Ana Maria Marino de Remes \\ Lenicov ${ }^{4}$
}

${ }^{1}$ Instituto de Microbiología y Zoología Agrícola - CONICET/INTA, Dr. Nicolas Repeto y de los Reseros, Hurlingham 1686, Buenos Aires, Argentina, ${ }^{2}$ PROIMI, Biotecnología - CONICET, Av. Belgrano y Pje. Caseros, San Miguel de Tucumán 4000, Tucumán, Argentina, ${ }^{3}$ Fundación Miguel Lillo, Miguel Lillo 251, San Miguel de Tucumán 400, Tucumán, Argentina, and ${ }^{4}$ Unidades de Investigación Anexo Museo, División de Entomología (FCNyM-UNLP-CIC), calle 60 y 122, s/n, La Plata 1900, Argentina

*Correspondence: Alvaro Foieri, Instituto de Microbiología y Zoología Agrícola CONICET/INTA, Dr. Nicolas Repeto y de los Reseros, Hurlingham 1686, Buenos Aires, Argentina. E-mail: afoieri@conicet.gov.ar

Short title: Effect of host plant on Notozulia entreriana: rearing method

Key words: Auchenorrhyncha, Cercopidae, Hemiptera, pest, forage species, pastures, breeding

This article has been accepted for publication and undergone full peer review but has not been through the copyediting, typesetting, pagination and proofreading process, which may lead to differences between this version and the Version of Record. Please cite this article as doi: 10.1111/EEA.12950

This article is protected by copyright. All rights reserved 
units, Neotropical region, Poaceae, Notozulia entreriana, spittlebug

Accepted: 19 February 2020
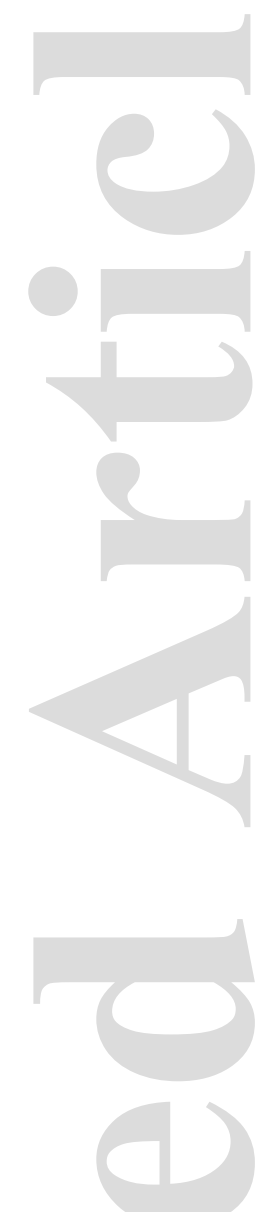

This article is protected by copyright. All rights reserved 


\section{Abstract}

Among the species belonging to 11 genera of Neotropical spittlebugs attacking graminaceous plants, Notozulia entreriana (Berg) (Hemiptera: Cercopidae) is one of the most important pests of grasses in several countries of South America. In this study we evaluate the influence of three economically relevant species of host plants (Poaceae) on life-cycle traits of $N$. entreriana. We tested for differences in fitness responses (survival and fecundity) of insects on forage species which are frequent hosts for wild populations of spittlebugs. Comparison of life cycles on three host plants showed that only $2.5 \%$ of nymphs completed their development on Zea mays L., $22.5 \%$ on Chloris gayana Kunth, and 95\% on Brachiaria decumbens Stapf. All the above suggests that $C$. gayana and $B$. decumbens are able to sustain complete development, behaving like natural hosts; the latter species is superior for artificial colonies because a shorter developmental period, higher survivorship in nymphs, and longer lifespan of adults were observed. Zea mays did not allow proper development, causing high mortality instead. We also developed a new approach for small-scale breeding of $N$. entreriana, which will enable subsequent biological and behavioral studies about this important pest species.

\section{Abbreviated abstract}

Notozulia entreriana (Hemiptera: Cercopidae) is an important pest of grasses in several countries of South America. We evaluated the influence of three economical Poaceae species of host plants on its life cycle. We tested for differences in fitness responses (survival and fecundity) of insects on forage species that frequently host wild populations of spittlebugs. We also developed a new approach for small-scale breeding, which will permit other biological and behavioral studies on this important pest species.

\section{Graphic for Table of Contents}

Figure 1

This article is protected by copyright. All rights reserved 


\section{Introduction}

There are at least 11 genera of spittlebugs (Hemiptera: Cercopidae) attacking graminaceous plants in a range extending from southern USA to South America, in humid and sub-humid areas within rangelands devoted to extensive and intensive grazing systems (Sanz, 1997; Thompson, 2004; Leite et al., 2005). Because of their wide geographic distribution and severe damage to host plants, spittlebugs represent the most important biological threat for the production and sustainability of forage grasses in the Neotropical region (Valérío \& Nakano, 1987; Valério et al., 1996). Population outbreaks of these insects dramatically reduce quality, production, and palatability of forage, decreasing persistence of prairies and increasing environmental degradation (Valérío \& Nakano, 1987).

Spittlebugs feed almost exclusively on xylem sap and, depending on the species, they can be from oligophagous to widely polyphagous on an ample variety of plants (Raven, 1983; Denno \& Perfect, 1994; Carvalho \& Webb, 2005). In Central and South America, there are many species of native and exotic grasses susceptible to attacks of these insects, such as Axonopus marginatus (Trin.) Chase, Cenchrus ciliaris L., Cynodon dactylon (L.), Panicum maximum Jacq, and Pennisetum americanum (L.) Leeke (Thompson, 2004), as well as sugarcane (Saccharum officinarum L.) (Peck et al., 2001), maize (Zea mays L.) (Janes, 1971; Peck et al., 2001; Paladini et al., 2008a), and rice (Oryza sativa L.) (Suji et al., 2001; Chen \& Liang, 2012). Urochloa decumbens (Stapf) R.D. Webster (= Brachiaria decumbens Stapf), widely distributed in Brazil, is also highly susceptible to several species of Cercopidae (Keller-Grein et al., 1966).

Notozulia entreriana (Berg) is one of the most important pests of grasses in several countries of South America. It has a wide distribution from southern USA to northern Argentina and is often abundant (Holmann \& Peck, 2002). In South America, injury caused by this species reduces plant growth, which makes pastures less interesting for farmers (Koller \& Valerio, 1985). Toxic salivary secretions injected during feeding interfere with photosynthetic activity, leaving chlorotic lesions which develop longitudinally and later became necrotic (Valério \& Nakano, 1987, 1992; Valério et al., 2001; Paladini et al., 2008b). Large areas of forage grasses are susceptible to damage by spittlebugs when weather conditions favor the probability of outbreaks of $N$. entreriana, which can exhibit three generations between November and April (Gomez, 1997). During certain years, population outbreaks can attain such high levels of abundance that part of the spittlebug population is forced to migrate from grasses to nearby annual crops such as maize and rice, which is made possible because adults can fly $5 \mathrm{~km}$ or more (Cosenza et al., 1982, 
1989; Santos et al., 1982; Souza \& Nilakhe, 1985; Carneiro \& Cunha, 1986).

Up to now, there is no information about how different hosts affect development or performance of the species. Current information about $N$. entreriana covers adult morphology and ultrastructure (Paladini et al., 2008b), diversity of wing color patterns (Koller \& Valeiro, 1984), geographic distribution (Foieri et al., 2015), host plants and morphology of immatures (Foieri et al., 2016), dynamics of diapausing eggs (Koller \& Valério, 1985; Koller \& Honer, 1993), and damage analysis on crops (Holmann \& Peck, 2002). Technical reports by Domingues \& da Silva Santos (1975) and Ferreira de Lima (1983) contributed to knowledge on population dynamics of the species. Studies on other pest species in the family Cercopidae are unfortunately lacking, and knowledge on the biology of most spittlebug species is still insufficient.

An important limitation for biological research is the difficulty of maintaining colonies. Researchers have attempted several methods of rearing cercopids for more than one generation in controlled environments. Hagley (1967) developed an artificial diet for feeding adult colonies of Aenolamia varia saccharina (Distant). Fewkes \& Demidecki-Demidowicz (1971) were able to rear two Aenolamia species for some generations, within an aluminum box in which sweet maize plants were grown on sand moistened with a nutrient solution via fiber-glass wicks. Chen \& Liang (2012) reared nymphs of Callitettix versicolor (Fabricius) by holding them in plastic food storage bins, and a Petri dish with moistened cotton was added plus a piece of filter paper for oviposition. Lapointe et al. (1989) developed a technique for mass rearing of cercopid species in a greenhouse, using wooden cages with a mud floor for oviposition. Peck et al. (2004) accomplished a smallscale rearing of several developmental stages of Aenolamia varia (Fabricius) on Brachiaria ruziziensis Germ. \& Evrard, using boxes with host plants on mounds of soil and emergence cages for capture of adults. The oviposition substrate and egg extraction technique were identical to those described in Lapointe et al. (1989). However, most of these rearing methods need periodical collections of wild adults from the field in order to keep sufficient population numbers in colony cages. All the preceding attempts support the necessity of developing ways to enable continuous reproduction of insects under artificial conditions. Indeed, laboratory colonies are necessary for the study of pest species and for the design of control strategies, and it is important to take into account variation in fitness due to different hosts as feeding resources. Plant-related factors, such as toxicity, nutrient contents, and physical characteristics, greatly influence the population dynamics of these insects, directly modifying life cycle length and female reproductive potential (Botelho et al., 1977; Mendes et al., 1977; Barbosa et al., 1979). 
The current study determines how plant species influence life cycle traits of $N$. entreriana. We tested for differences in fitness responses (survival and fecundity) of insects across a range of forage species, which are frequently hosts of wild populations of spittlebugs in maize agroecosystems. Also, a new technique is proposed to rear this insect in the laboratory.

\section{Materials and methods}

\section{Host plants}

To select plants to be used as hosts for insects in the experiments, we checked previous records of the natural abundance of adults and nymphs of $N$. entreriana on natural grasslands and cultivated pastures in agricultural areas from northern Argentina. Consequently, Brachiaria decumbens Stapf, Chloris gayana Kunth var. epica, and Zea mays L. (all Poaceae) were selected as treatments. These species are $\mathrm{C} 4$ grasses, with associative $\mathrm{N}$-fixation, and are of economic interest because they are used as crops or forage grasses (Thompson, 2004), maize being one of the most important cereal crops for the Argentinean economy (USDA, 2014).

Host plants were obtained from seeds provided by the National Institute of Agricultural Technology (INTA), Leales, Tucumán, which were allowed to germinate in small pots for 2 weeks. Seedlings were transplanted to larger pots with soil, or 'breeding units' as will be described.

\section{Insects}

Insect samples were obtained from a non-cropped field in San Miguel de Tucumán, Tucumán,

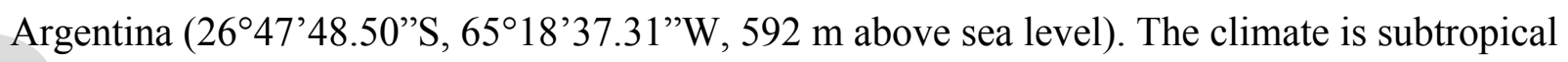
with marked seasonality and during the rainy season, three generations of $N$. entreriana occur during summer and fall, between October and May (A Foieri, pers. obs.). Before the start of the experiments, male and female adults were sampled during those population peaks in order to obtain eggs to start colonies. Females were individually transferred to oviposition cages. These were cylindrical containers ( $35 \mathrm{~cm}$ high, $18 \mathrm{~cm}$ diameter) made of polyethylene terephthalate (PET), holding a single plant in a small pot with fertile soil. A cotton pad was placed around the basis of the plant stem in order to provide an oviposition substrate. Every day, cotton pads were removed, eggs were extracted under a stereomicroscope, and later maintained on humid filter paper inside Petri dishes until full embryonic development.

This article is protected by copyright. All rights reserved 


\section{Life cycle studies on different host plants}

Experiments were carried out between January and May 2014, in an AR-36L climate-controlled plant growth chambers (Percival, Perry, IA, USA) at $26 \pm 1{ }^{\circ} \mathrm{C}, 60-80 \%$ r.h., and L14:D10 photoperiod. Each treatment consisted of 40 breeding units (i.e., 40 replicates) (Figure 1A), each composed of a 180-ml polystyrene pot partially filled with soil and a single plant of each species. Plants across all experimental replicates were in the same phenological stage (approximately 3 weeks after germination).

A single egg of $N$. entreriana was placed in each breeding unit on the soil and close to the plant stem, and the surface was covered with a black PET capsule. The latter was built with an inverted black-painted polystyrene pot with a hole in the center encircling the plant stem (Figure 1). After hatching of eggs, black PET capsules were temporarily removed every day to record nymphal status and presence or absence of exuviae.

\section{Adults}

As individuals reached adulthood, they were extracted from breeding units with a hand aspirator, sexes were recorded, and then transferred to oviposition cages (Figure 1B) to continue insect development. Polyethylene terephthalate bottles $(500 \mathrm{ml})$ were used as cages, with a cotton plug on the top, holding a single plant as a food source, and a cotton pad on the base to allow oviposition. Pairs of $N$. entreriana were confined inside bottles in order to ensure mating and egg laying. To ensure male presence throughout the lifespans of females, every dead male was replaced. All eggs laid were counted; egg counting continued until females died.

\section{Data analysis}

Response variables were nymphal development time in days, adult longevity in days, and fecundity (no. eggs laid per female per day). Differences between male and female nymphal development time and adult longevity were tested with t-tests or Mann-Whitney U tests for two independent samples, when data distribution was normal or not normal after transformation, respectively. Adult longevity and fecundity were ln-transformed and compared between host plants (treatments) as the main source of variation; then a parametric ANOVA (type III sum of squares) was run to test the effects of treatment, sex, and their interaction, followed by Fisher's least significant difference (LSD) tests to differentiate means. Analysis was done using IBM SPSS Statistics v.22 (2013). For all cases, the level of significance was $\alpha=0.05$. To calculate a rough 
approximation of fitness (F') of spittlebugs, we estimated it as the product of survival ( $\left.\mathrm{S}^{\prime}\right)$

(longevity) and fecundity (I'), for every treatment (Dawkins, 1982).

\section{Results}

\section{Development time}

Mean development time of nymphs (all instars pooled) did not differ between treatments with $B$. decumbens vs. C. gayana (B. decumbens: mean $\pm \mathrm{SD}=25.7 \pm 1.3$ days; C. gayana: $26.4 \pm 1.51$ days; $\mathrm{t}$-test for independent samples: $\mathrm{t}=-1.52$, d.f. $=45, \mathrm{P}=0.14$; Table 1). Most nymphs born on B. decumbens reached adulthood (95\%), a total of 14 males and 24 females, all of which produced offspring. On C. gayana, only $22.5 \%$ of the nymphs reached the adult stage - nine individuals in total, three males and six females, all of which laid eggs. Young nymphs showed $50 \%$ mortality by the 3 rd day of development.

Adult longevity differed significantly between host plants, sexes, and their interaction (Table 2). Males raised on B. decumbens lived shorter than in other combinations of treatments and sex (Fisher LSD = 2.17, $\mathrm{P}<0.05$; Figure 2). Adults (pooled sexes) lived longer on Chloris (mean $\pm \mathrm{SD}=9.56 \pm 1.24$ days) than on Brachiaria $(7.63 \pm 3.004$ days $)(\mathrm{t}=-3.02, \mathrm{P}=0.005)$.

On $B$. decumbens, individuals reached the adult stage between days 26 and 31, and males developed faster than females (males: mean $\pm \mathrm{SD}=5.47 \pm 2.18$ days; females: $9.43 \pm 2.08$ days; $\mathrm{t}$ $=6.49$, d.f. $=36, \mathrm{P}<0.0001$ ). The whole life cycle for males and females (excluding the egg stage) averaged 30.5 and 34.9 days, respectively, with a sex ratio in the offspring of 1:1.5 (males-tofemales). On C. gayana, the mean number of days to adulthood did not differ between the sexes ( $\mathrm{t}$ $=1.69$, d.f. $=7, P=0.13$ ). Individuals reached the adult stage between days 28 and 33 . The life cycle for males and females (excl. egg stage) took on average 36.6 and 37.9 days, respectively, with an offspring sex ratio of 1:2 (males-to-females).

Nymphal developmental time, adult longevity, and offspring sex ratio were not estimated for Z. mays because only a single individual completed its development up to the adult stage (Table 1).

\section{Fecundity}

Mean lifetime fecundity of $N$. entreriana did not differ between host plants (B. decumbens: mean $\pm \mathrm{SD}=32.21 \pm 24.75$ eggs, $\mathrm{n}=24$; C. gayana: $19.50 \pm 10.07$ eggs, $\mathrm{n}=6$; Mann-Whitney $\mathrm{U}$ test: $\mathrm{W}=72.50, \mathrm{P}=0.28$ ) (Table 1$)$. On $B$. decumbens, females showed a mean $( \pm \mathrm{SD})$ preoviposition 
period of $3.6 \pm 14$ days $(n=24)$. Maximum lifetime number of eggs laid by a single female was 98. Maximun number of eggs deposited by 24 females in a single day was 261 . Females laid more than $50 \%$ of eggs during 2 days after the preoviposition period, showing a peak on day 6 of adult life and a second, lower peak on day 9 (Figure 3). After day 10, there was no further oviposition. Development time of eggs ranged from 14 to 16 days $(15.3 \pm 0.5 ; n=40)$.

On C. gayana, females had a mean $( \pm \mathrm{SD})$ preoviposition period of $4.2 \pm 0.8$ days $(\mathrm{n}=6)$. The maximum number of eggs laid by a female was 36 . The maximun number of eggs deposited by six females in a single day was 35 . Females laid more than $50 \%$ of their eggs during 2 days after the preoviposition period, showing a peak on day 6 of adult life and a second, lower peak on day 10 (Figure 3). After day 11, there was no further oviposition. Development time of eggs ranged between 14 and 18 days $(15.4 \pm 1.3$ eggs; $n=40)$.

On Z. mays, a single female completed its life cycle. Thus, results from this species were dropped from the analysis. The preoviposition period of this individual was 3 days and lifetime fecundity was 66 eggs; she laid 34 eggs in a single day. On average, oviposition rate was 16.5 eggs per day, with a peak between on day 7; after day 8 oviposition stopped.

Comparison between performances of spittlebugs across plants species, using a simple index (F') as a proxy for fitness, showed that fitness achieved on C. gayana was $12 \%$ of that achieved on B. decumbens, and fitness on Z. mays could not be estimated (Table 1).

By providing a suitable host, the rearing method used in this study proved to be effective for sustaining bugs over more than one generation in the laboratory. Both, cotton pads and breeding units, as well as the black PET capsules conferred conditions under which eggs were obtained and nymphs developed.

\section{Discussion}

The life cycle of $N$. entreriana differed greatly among the three host plants offered. Only $2.5 \%$ of nymphs completed their development on $Z$. mays (one individual reached adulthood), $22.5 \%$ on $C$. gayana, and $95 \%$ on $B$. decumbens. Development rate was not significantly different on $C$. gayana vs. B. decumbens. On average adults lived longer on $C$. gayana than on B. decumbens. These results indicate that $C$. gayana and B. decumbens are able to support complete development of $N$. entreriana. The latter host appears preferable for laboratory culturing due to the higher survivorship of nymphs and the higher fecundity of adults. The unsuitability of $Z$. mays as a host may be related to plant defence reactions, e.g., via volatiles such as (E)-b-farnesene, methyl 
salicylate, various terpenoids, and linalool (Chapman et al., 1981; Hardie et al., 1994; Bernasconi et al., 1998) or via chemical compounds in xylem sap (benzoxazinoids and chlorogenic acid) (Raven, 1983; Andersen et al., 1992, Press \& Whittaker, 1993; Louis et al., 2015).

According to Sujii et al. (2001) the fact that nymphs of spittlebugs are sedentary means that reproduction and fecundity depend on resources acquired by females during adulthood. Females may compensate for low-quality hosts during nymphal instars with different strategies such as polyphagy or plasticity in the preovipositional period. Although females of $N$. entreriana bred on C. gayana live longer, those bred on $B$. decumbens produced a higher number of eggs. Both hostplant species are associated with nitrogen-fixing rhizobacteria in the soil (Boddey \& Victoria, 1986; Döbereiner \& Pedrosa, 1987) but B. decumbens, unlike C. gayana, has a large root biomass helping to increase the diversity, number, and activity of microorganisms in the rhizosphere. This will improve soil quality, increasing organic matter and thus the amount of $\mathrm{C}, \mathrm{P}$, and $\mathrm{N}$ available. As a result, the host plant gets higher-quality nutrients that are essential for xylem-sap feeders such as spittlebugs (Thompson, 1994; Pires et al., 2000; Sujii et al., 2001; Gichangi et al., 2016). These factors could partly explain the results of our experiments.

In the present work, we present a new approach for small-scale breeding of $N$. entreriana, which will allow other biological and behavioral studies on this important pest species. The new approach may be adaptable for use with other species of Cercopidae; it requires limited infrastructure and manpower, is inexpensive, and is little time-consuming. Fewkes \& DemideckiDemidowicz (1971) and Peck et al. (2004) made rearing units with large aluminum boxes and trays with soil and plants. In order to obtain eggs, they extracted them by washing soil with water and passing the resulting liquid through a series of sieves to remove coarse particles, followed by egg flotation in saline solutions at different concentrations. Unlike those earlier rearing units, our breeding units were built with recycled materials (beakers and plastic bottles) and as they demand little space, a high number of replicates can be allotted to a small space. Moreover, no additional devices were necessary for extracting eggs. Consequently, our design is simpler and especially appropriate for tracking events throughout an individual's lifetime, rather than for mass-rearing.

We attribute the success in using breeding units to the good conditions for nymphal growth, providing them a dark and humid environment. The combination of individual breeding units, black PET capsules, and cotton pads resulted in an easy and efficient way to raise populations, suitable for host-range studies or other environmental factors that affect the dynamics of insects. The success of continuous breeding allows for future research on the biology, genetics, 
and behavior of spittlebugs, contributing to the development of control programs of this important pest.

\section{Acknowledgements}

This study was supported by the National Research Council (Consejo Nacional de Investigaciones Científicas y Técnicas, CONICET) and National University of La Plata (UNLP, Argentina) (project code 730). We also appreciate the thoughtful and constructive suggestions from the reviewers, which greatly improved the original manuscript.

\section{References}

Andersen PC, Brodbeck VB \& Mizell RF (1992) Feeding by the leafhopper, Homalodisca coagulata, in relation to xylem fluid chemistry and tension. Journal of Insect Physiology 38: $611-622$.

Barbosa JT, Riscado GM \& Lima Filho M (1979) Flutuação populacional da cigarrinha da canade-açúcar e seus inimigos naturais em Campos RJ, em 1977. Anais da Sociedade Entomológica do Brasil 8: 39-46.

Bernasconi ML, Turlings TCJ, Ambrosetti L, Bassetti P \& Dorn S (1998) Herbivore-induced emissions of maize volatiles repel the corn leaf aphid, Rhopalosiphum maidis. Entomologia Experimentalis et Applicata 87: 133-142.

Boddey RM \& Victoria RL (1986) Estimation of biological nitrogen fixation associated with Brachiaria and Paspalum grasses using ${ }^{15} \mathrm{~N}$ labelled organic matter and fertilizer. Plant Soil 90: 265-313.

Botelho PSM, Mendes AC, Macedo N \& Silveira Neto S (1977) Curva populacional de Mahanarva fimbriolata em Araras - SP, e sua dependência com o balanço hídrico da região. Brasil Açucareiro 90: 11-17.

Carneiro M de F \& da Cunha HF (1986) Avaliação de danos e controle químico da cigarrinha-daspastagens (Deois flavopicta) na cultura do milho. Goiânia, EMGOPA. Boletim de Pesquisa 7: $1-13$.

Carvalho GS \& Webb M (2005) Cercopid Spittle Bugs of the New World (Hemiptera, Auchenorrhyncha, Cercopidae). Pensoft, Sofia, Bulgaria.

Chapman RF, Bernays EA \& Simpson SJ (1981) Attraction and repulsion of the aphid Cavariella aegopodii by plant odors. Journal of Chemical Ecology 7: 881-888.

This article is protected by copyright. All rights reserved 
Chen X \& Liang A (2012) Laboratory rearing of Callitettix versicolor (Hemiptera: Cicadomorpha: Cercopidae), with descriptions of the immature stages. Annals of the Entomological Society of America 105: 664-670.

Cosenza GW, de Andrade RP, Gomes DT \& da Rocha CMC (1982) O Controle Integrado das Cigarrinhas das Pastagens. EMBRAPA-CPAC Comunicado Técnico 17: 1-6.

Cosenza GW, de Andrade RP, Gomes DT \& da Rocha CMC (1989) Resistência de gramíneas forrageiras à cigarrinha-das-pastagens. Pesquisa Agropecuária Brasileira 24: 961-968.

Dawkins R (1982) The Extended Phenotype - The Gene as the Unit of Selection. Oxford University Press, Oxford, UK.

Denno RF \& Perfect TJ (1994) Planthoppers - Their Ecology and Management. Chapman \& Hall, New York, NY, USA.

Döbereiner J \& Pedrosa FO (1987) Nitrogen-Fixing Bacteria in Nonleguminous Crop Plants.

Science Tech Publishers, Madison, WI, USA.

Domingues FM \& da Silva Santos EMS (1975) Estudo da Biologia da Cigarrinha das Pastagens Zulia entreriana Berg, 1879, e Sua Curva Populacional no Norte do Estado do Espírito Santo. Boletim Técnico, no. 2, EMCAPA, Vitória, Brazil.

Ferreira de Lima M (1983) Flutuação populacional de Zulia enteriana em pastagens de Brachiaria decumbens, Cenchrus ciliares e Digitaria decumbens, em diferentes regiões do Estado de Sergipe. Pesquisa em Andamento, EMBRAPA 20: 1-5.

Fewkes DW \& Demidecki-Demidowicz MR (1971) Rearing technique for sugar cane froghopper nymphs (Homoptera: Cercopidae). Annals of the Entomological Society of America 64: $1471-1472$.

Foieri A, Virla GE \& Marino de Remes Lenicov AM (2015) New host plants records for the froghopper Notozulia entreriana (Hemiptera: Cercopidae) with new data on its occurrence in diverse ecological zones in Argentina. Revista de la Sociedad Entomológica Argentina 74: 79-84.

Foieri A, Marino de Remes Lenicov AM \& Virla GE (2016) Descriptions of the immature stages and new host plant records of Notozulia entreriana (Berg) (Hemiptera: Cercopidae) pests of grasses in subtropical areas of the Americas. Zootaxa 4103: 54-62.

Gichangi EM, Njarui DMG, Gatheru M, Magiroi KWN \& Ghimire SR (2016) Effects of Brachiaria grasses on soil microbial biomass carbon, nitrogen and phosphorus in soils of the semi arid tropics of Kenya. Tropical and Subtropical Agroecosystems 19: 193-203.

This article is protected by copyright. All rights reserved 
Gomez SA (1997) Controle químico da cigarrinha-das-pastagens, Zulia entreriana (Berg., 1879) (Homoptera: Cercopidae), na cultura do milho. EMBRAPA-CPAO Comunicado Técnico 24: $1-5$.

Hagley EAC (1967) Artificial diet for the adult froghopper. Nature 213: 414-414.

Hardie J, Isaacs R, Pickett JA, Wadhams LJ \& Woodcock CM (1994) Methyl salicylate and (-)(1R,5S)-myrtenal are plant-derived repellents for black bean aphid, Aphis fabae Scop. (Homoptera: Aphididae). Journal of Chemical Ecology 20: 2847-2855.

Holmann F \& Peck DC (2002) Economic damage of grassland spittlebugs (Homoptera: Cercopidae) in Colombia: a first approximation of impact on animal production in Brachiaria decumbens. Neotropical Entomology 31: 275-284.

Janes MJ (1971) Two-lined spittlebug adults severely damage sweet corn seedlings. Journal of Economic Entomology 64: 976-977.

Keller-Grein G (1966) Reunión de la Red Internacional de Evaluación de Pastos Tropicales (RIEPT)-Amazonia, Lima, Perú. Working document no. 75. INIAA, IVITA, and CIAT, Cali, Colombia 2: 859-862.

Koller WW \& Valério JR (1984) Padrões alares de Zulia entreriana em Campo Grande, MS. Pesquisa Agropecuária Brasileira 19: 799-803.

Koller WW \& Valério JR (1985) Períodos de incubação de ovos de Zulia entreriana (Berg, 1879) (Homoptera: Cercopidae) obtidos em diferentes épocas. Pesquisa em Andamento 27: 1-5.

Koller WW \& Honer MR (1993) Correlações entre fatores climáticos e a dinâmica de produção de ovos diapáusicos de duas espécies de cigarrinhas-das-pastagens (Homoptera; Cercopidae). Anais da Sociedade Entomológica do Brasil 22: 597-621.

Lapointe SL, Sotelo G, Serrano MS \& Arango G (1989) Cría masiva de especies de cercópidos en invernadero. Pasturas Tropicales 11: 25-28.

Leite LG, Machado LA, Goulart RM, Tavares FM \& Filho AB (2005) Screening of entomopathogenic nematodes (Nemata: Rhabditida) and the efficiency of Heterorhabditis sp. against the sugarcane root spittlebug Mahanarva fimbriolata (Fabr.) (Hemiptera: Cercopidae). Neotropical Entomology 34: 785-790.

Louis J, Basu S, Varsani S, Castano-Duque L, Jiang V et al. (2015). Ethylene contributes to maize insect resistancel-mediated maize defense against the phloem sapsucking corn leaf aphid. Plant Physiology 169: 313-324.

Mendes AC, Botelho PSM, Macedo N \& Silveira Neto S (1977) Behavior of the adults of the root

This article is protected by copyright. All rights reserved 
froghopper, Mahanarva fimbriolata (Stål, 1854) (Hom., Cercopidae), according to climatic parameters. Proceedings of the Sociedad Internacional de Tecnólogos Azucareros 16: 617631.

Paladini A, Ferreira A \& Carvalho GS (2008a) Cladistic analysis of Kanaima Distant, 1909 (Hemiptera, Cercopidae). Zootaxa 1704: 47-63.

Paladini A, Carvalho GS \& Valério JR (2008b) Ultrastructure and redescription of Notozulia entreriana (Berg) (Hemiptera: Cercopidae). Neotropical Entomology 37: 552-557.

Peck D, Castro U, Lopez F, Morales A \& Rodriguez J (2001) First records of the sugar cane and forage grass pest, Prosapia simulans (Homoptera: Cercopidae), from South America. Florida Entomologist 84: 402-409.

Peck CD, Morales A \& Castro U (2004) Alternative methods for rearing grass-feeding spittlebugs (Hemiptera: Cercopidae). Neotropical Entomology 33: 307-314.

Pires CSS, Price PW \& Fontes EG (2000) Preference performance linkage in the neotropical spittlebug Deois flavopicta, and its relation to the phylogenetic constraints hypothesis. Ecological Entomology 25: 71-80.

Press MC \& Whittaker JB (1993) Exploitation of the xylem stream by parasitic organisms. Philosophical Transactions of the Royal Society of London B 341: 101-111.

Raven JA (1983) Phytophages of xylem and phloem: a comparison of animal and plant sapfeeders. Advances in Ecological Research V13: 135-234.

Santos JP, Cruz I \& Botelho W (1982) Avaliação de dano e controle da cigarrinha-das- pastagens em plantas de milho com diferentes idades. Pesquisa em Andamento 2: 1-9.

Sanz NT (1997) Checklist of Pests and Diseases of Selected Crops of Belize. Belize National Plant Protection Service, Ministry of Agriculture and Fisheries, Central Farm, Cayo District, Brazil.

Souza ARR \& Nilakhe SS (1985) Avaliação de danos e controle químico das cigarrinhas-daspastagens em culturas de arroz. Anais da Sociedade Entomologica do Brasil 14: 177-188.

Sujii ER, Pires CSS, Fontes EMG \& Garcia MA (2001) Effect of host plant on the fecundity of spittlebug Deois flavopicta Stal (Homoptera: Cercopidae): implications on population dynamics. Neotropical Entomology 30: 547-552.

Thompson V (1994) Spittlebug indicators of nitrogen-fixing plants. Ecological Entomology 19: 391-398.

Thompson V (2004) Associative nitrogen fixation, C4 photosynthesis, and the evolution of 
spittlebugs (Hemiptera: Cercopidae) as major pests of Neotropical sugar cane and forage grasses. Bulletin of Entomological Research 94: 189-200.

USDA (2014) Grain: World Markets and Trade. United States Department of Agriculture, Beltsville, MD, USA.

Valério JR \& Nakano O (1987) Dano causado por adultos da cigarrinha Zulia entreriana (Berg, 1879) (Homoptera: Cercopidae) na produção de raízes de Brachiaria decumbens Stapf. Anais da Sociedade Entomológica do Brasil 16: 205-212.

Valério JR \& Nakano O (1992) Sintomatologia dos danos causados pelo adulto da cigarrinha Zulia entreriana (Berg, 1879) (Homóptera, Cercopidae) em Brachiaria decumbens Stapf. Anais da Sociedade Entomológica do Brasil 21: 95-100.

Valério JR, Lapointe SL, Kelemu S, Fernandes CD \& Morales SJ (1996) Pests and diseases of Brachiaria species. Brachiaria: Biology, Agronomy and Improvement (ed by JW Miles, BL Maass \& CB do Valle), pp 87-105. CIAT, Cali, Colombia.

Valério JR, Cardona C, Peck DC \& Sotelo G (2001) Spittlebugs: bioecology, host plant resistance and advances in IPM. Proceedings of the XIX International Grassland Congress, pp. $217-$ 221. FEALQ, Piracicaba, Brazil.

\section{Figure captions}

Figure 1 Small-scale breeding of Notozulia entreriana. (A) Breeding units covered with black PET capsules; nymphs were held beneath the black capsules. (B) Adult oviposition cages made of PET bottles, containing a host plant and a cotton pad for egg-laying.

Figure 2 Mean (+ SE) longevity (days) of Notozulia entreriana adults on Brachiaria decumbens and Chloris gayana var. epica as host plants. Means capped with the same letter are not significantly different (Fisher's LSD test: $\mathrm{P}<0.05$ ).

Figure 3 Mean daily oviposition (no. eggs per female per day) of Notozulia entreriana reared on Brachiaria decumbens $(\mathrm{n}=24)$ and Chloris gayana var. epica $(\mathrm{n}=6)$.

This article is protected by copyright. All rights reserved 
Table 1 Comparison of performances (mean $\pm \mathrm{SD}$ ) of Notozulia entreriana on Brachiaria decumbens, Zea mays, and Chloris gayana var. epica

\begin{tabular}{|c|c|c|c|c|c|c|c|}
\hline \multirow[t]{2}{*}{ Population parameter } & & \multicolumn{3}{|l|}{ Host plant } & \multirow[t]{2}{*}{$\mathrm{t}$} & \multirow[t]{2}{*}{ d.f. } & \multirow[t]{2}{*}{$\mathrm{P}$} \\
\hline & & B. decumbens & Z. mays & C. gayana & & & \\
\hline \multirow[t]{5}{*}{ Nymphal development time (days) } & Nymph I & $5.8( \pm 0.8)$ & - & $5.0( \pm 0.9)$ & 2.71 & 45 & $<0.01$ \\
\hline & Nymph II & $5.9( \pm 0.9)$ & - & $6.0( \pm 0.7)$ & -0.33 & 45 & 0.74 \\
\hline & Nymph III & $4.4( \pm 0.6)$ & - & $4.3( \pm 0.5)$ & 0.33 & 45 & 0.74 \\
\hline & Nymph IV & $5.3( \pm 0.7)$ & - & $6.4( \pm 1.0)$ & -4.13 & 45 & $<0.01$ \\
\hline & Nymph V & $4.3( \pm 0.9)$ & - & $4.7( \pm 1.4)$ & -1.08 & 45 & 0.28 \\
\hline Total nymph stage (days) & & $25.7( \pm 1.3)$ & - & $26.4( \pm 1.5)$ & -1.52 & & 0.14 \\
\hline$\%$ nymphs reaching the adult stage & & 95.0 & 2.5 & 22.5 & & & \\
\hline \multirow[t]{2}{*}{ Longevity (days) } & Males & $4.8( \pm 1.6)$ & - & $8.7( \pm 1.5)$ & -3.78 & 15 & $<0.01$ \\
\hline & Females & $9.3( \pm 2.3)$ & - & $10( \pm 0.9)$ & -1.20 & 25 & 0.24 \\
\hline Life expectancy $\left(e_{x}\right)$ at nymph emergence & & 28.8 & 6.7 & 16.7 & & & \\
\hline Age at which $50 \%$ of population died (days) & & 31 & 4 & 4 & & & \\
\hline Mean fecundity (no. eggs/female) (I') & & $32.21( \pm 24.7)$ & - & $19.05 \pm 10.1$ & $72.5^{1}$ & 29 & 0.29 \\
\hline Mean oviposition rate (no. eggs/female/day) & & 4.7 & - & 2.4 & & & \\
\hline Survival (proportion of surviving individuals from egg to adulthood) (S') & & 0.95 & 0.025 & 0.22 & & & \\
\hline Fitness ( $S^{\prime} \times$ I') & & 30.6 & - & 3.7 & & & \\
\hline Relative fitness & & 1 & - & 0.12 & & & \\
\hline
\end{tabular}

${ }^{1}$ Z-adjusted value of Mann-Whitney U test.

This article is protected by copyright. All rights reserved 
Table 2 Two-way ANOVA for the effects of treatment (Brachiaria decumbens vs. Chloris gayana var. epica) and sex (males vs. females) on the longevity of Notozulia entreriana adults

\begin{tabular}{lllll}
\hline Source & d.f. & MS & F & P \\
\hline Model & 3 & 1.62 & 21.43 & $<0.0001$ \\
Treatment & 1 & 0.89 & 11.74 & 0.0014 \\
Sex & 1 & 1.14 & 15.05 & 0.0004 \\
Treatment*sex & 1 & 0.47 & 6.15 & 0.017 \\
Error & 43 & 0.08 & & \\
Total & 46 & & & \\
\hline
\end{tabular}

This article is protected by copyright. All rights reserved 

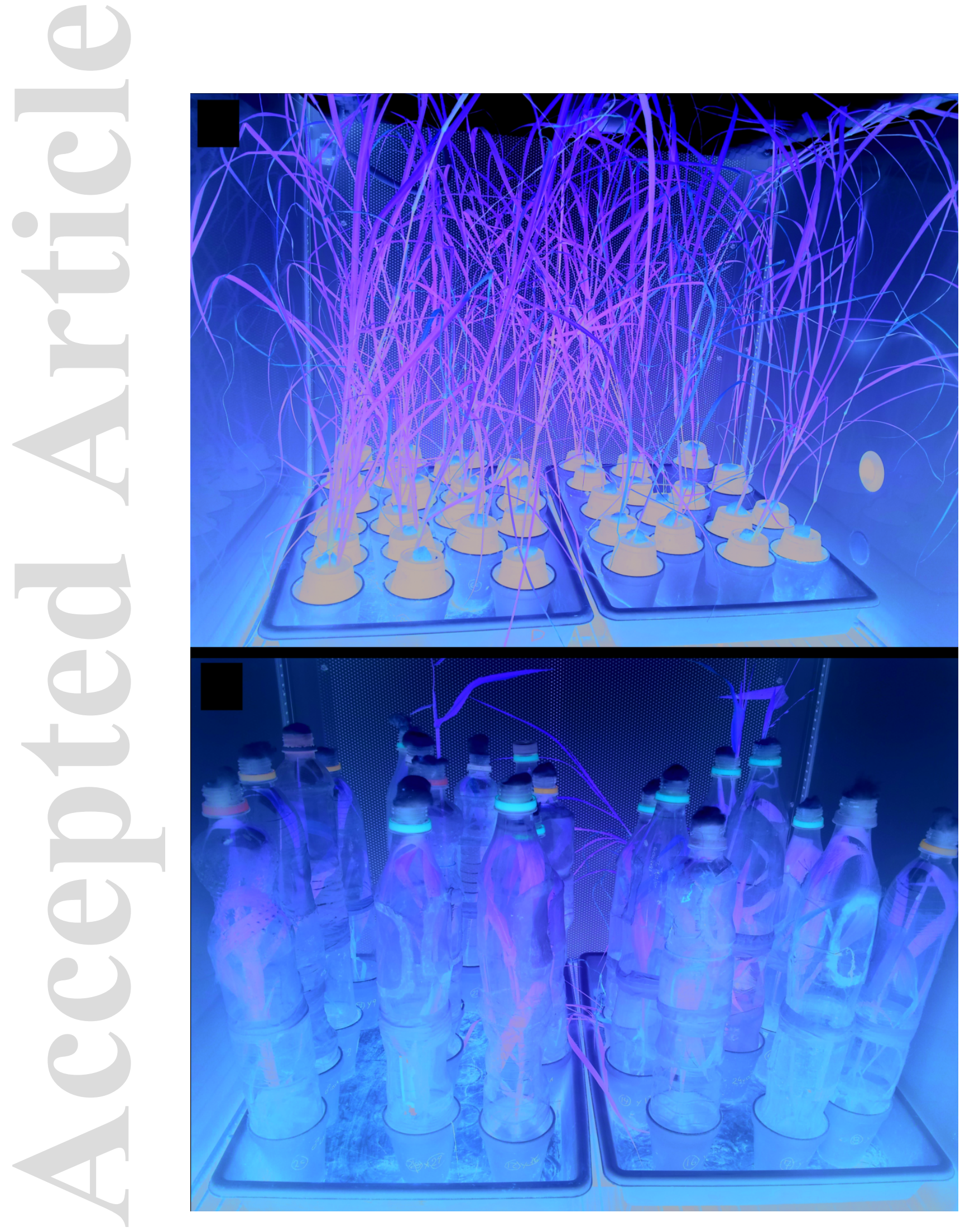

eea_12950_f1.tif

This article is protected by copyright. All rights reserved 


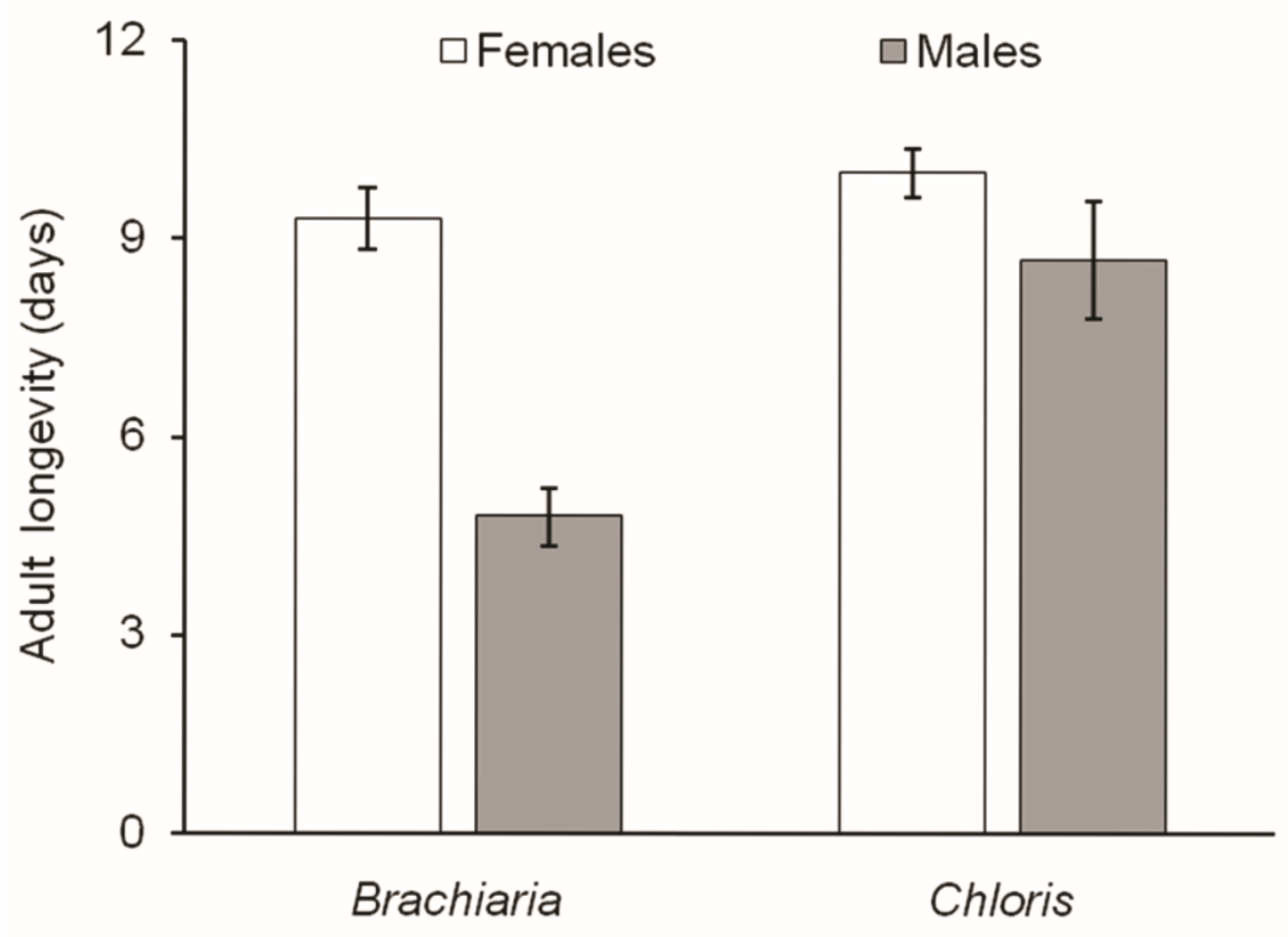

eea_12950_f2.tif

This article is protected by copyright. All rights reserved 


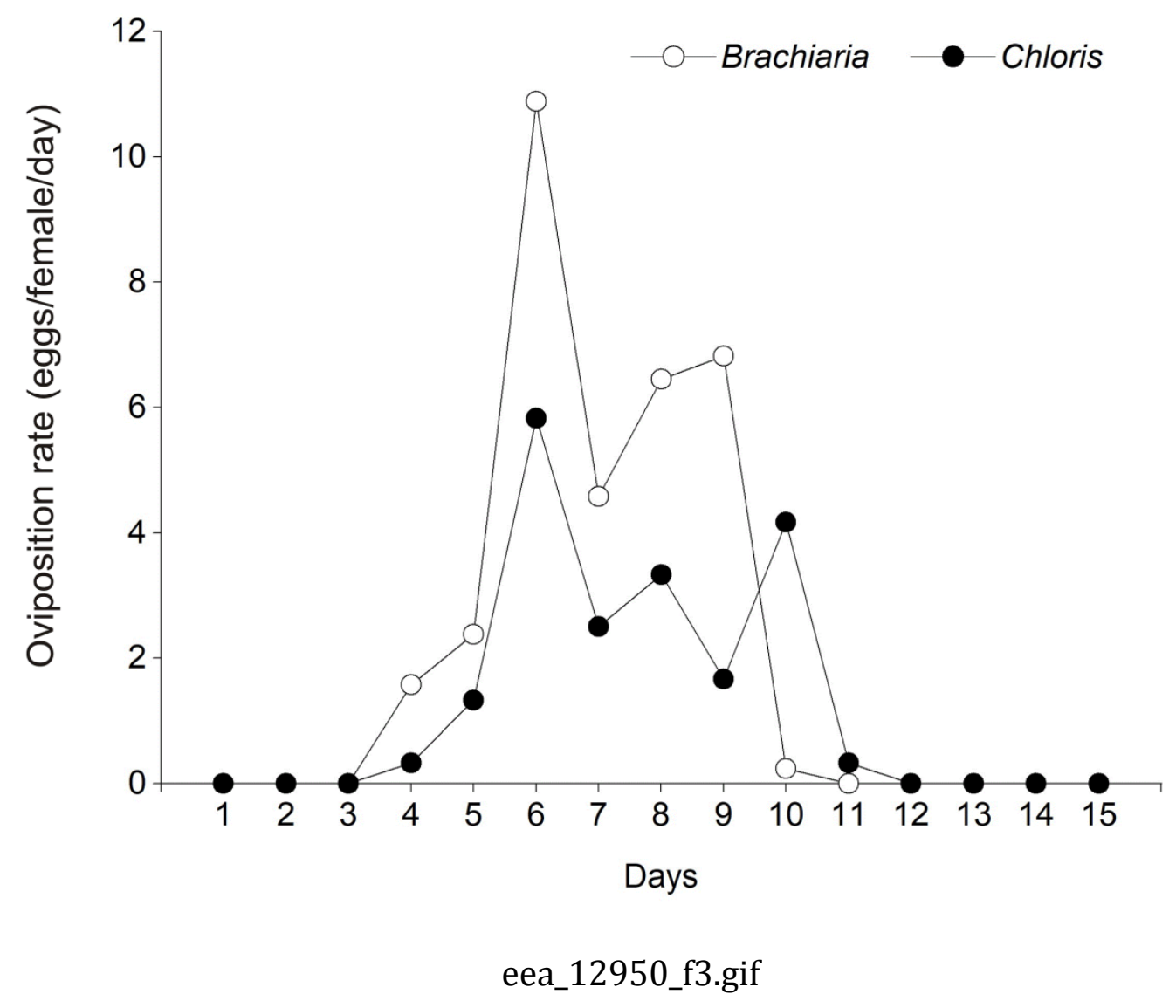

This article is protected by copyright. All rights reserved 